\title{
RANKING WYBRANYCH SPÓŁEK SEKTORA PRZETWÓRSTWA RYBNEGO W WOJEWÓDZTWIE POMORSKIM NA PODSTAWIE ANALIZY TAKSONOMICZNEJ
}

\section{RANKING OF SELECTED COMPANIES OF FISH PROCESSING SECTOR IN POMORSKIE VOIVODESHIP WITH APPLICATION OF TAXONOMIC ANALYSIS}

\author{
Katedra Zastosowań Matematyki w Ekonomii, Zachodniopomorski Uniwersytet Technologiczny \\ w Szczecinie, ul. Klemensa Janickiego 31, 71-270 Szczecin, ORCID: 0000-0001-8959-7269 \\ e-mail: iwona.bak@zut.edu.pl \\ ${ }^{1}$ Agencja Restrukturyzacji i Modernizacji Rolnictwa, Pomorski Oddział Regionalny w Gdyni, \\ doktorantka Katedry Zastosowań Matematyki w Ekonomii, Wydział Ekonomiczny ZUT w Szczecinie, \\ ORCID: 0000-0003-3313-4956, e-mail: zyta297@vp.pl \\ ${ }^{2}$ Katedra Analizy Systemowej i Finansów, Zachodniopomorski Uniwersytet Technologiczny \\ w Szczecinie, ul. Klemensa Janickiego 31, 71-270 Szczecin, ORCID: 0000-0002-7718-777X \\ e-mail: beata.szczecinska@zut.edu.pl
}

\begin{abstract}
Summary. The fish processing sector is one of the fastest growing agri-food sectors. The main factor affecting its development in Poland were the European Union funds, thanks to which our country was given a chance to reduce developmental backlog, improve innovation and improve its competitive position (within the sector and on the single European market). The purpose of the article is to apply taxonomic analysis to assess the financial situation of companies and to check whether their financial situation was affected by obtained EU funds. The study included companies that used EU funds and operated in the Pomeranian Voivodeship in 2015. The ordering and classification of the companies was carried out using the method of zeroed unitarisation.
\end{abstract}

Słowa kluczowe: sektor przetwórstwa rybnego, wskaźniki finansowe, metoda unitaryzacji zerowanej. Key words: fish processing sector, financial inicators, the zeroed unitarisation method.

\section{WSTĘP}

Sektor przetwórstwa rybnego, stanowiący znaczącą część sektora przemysłu spożywczego, jest jednym z najszybciej rozwijających się sektorów rolno-spożywczych. Po okresie wyraźnego zastoju w pierwszych latach wprowadzania gospodarki rynkowej nastąpiły w nim głębokie i radykalne zmiany restrukturyzacyjne, które pozwoliły na szybki wzrost konkurencyjności, a w konsekwencji - wzrost wielkości produkcji sprzedanej ogółem. (Czapliński 2011). Sektor ten należy jednocześnie do jednej z najmniejszych grup przemysłu spożywczego' ${ }^{1}$. Wynika to nie tylko z wielkości zatrudnienia, które według danych GUS w latach 2006-2014

\footnotetext{
${ }^{1}$ Przemysł przetwórstwa rybnego rozumiany jest jako działalność związana z przetwarzaniem i konserwowaniem ryb, skorupiaków i mięczaków. Według PKD jest to grupa 10.2 należąca do działu 10. o nazwie produkcja artykułów spożywczych oraz do sekcji C, określonej jako przetwórstwo przemysłowe.
} 
kształtowało się na średnim poziomie wynoszącym około 14 tys. osób (Kaliszewska 2016), a na koniec 2016 roku wyniosło 15,6 tys. pracujących, tj. 4,31\% zatrudnienia w dziale 10 (produkcja artykułów spożywczych), ale również z udziału ryb w imporcie i eksporcie rolno-spożywczym (odpowiednio 9,0\% i 7,0\%), a także z wielkości produkcji sprzedanej wynoszącej 9,4 mld zł, tj. 5,13\% produkcji sprzedanej w dziale 10, oraz z udziału podmiotów w ogólnej liczbie podmiotów działu 10 wynoszącej 0,7\% (Czapliński 2018).

Głównym czynnikiem mającym wpływ na rozwój tego sektora były fundusze Unii Europejskiej. Po przystąpieniu do niej Polska uzyskała dostęp do najważniejszych instrumentów oddziaływania europejskiej polityki regionalnej - funduszy strukturalnych (Nowak 2005; Sytuacja na światowym rynku... 2014). Środki finansowe z sektorowego programu operacyjnego „Rybołówstwo i przetwórstwo ryb 2004-2006”, przeznaczone na przetwórstwo i rynek rybny, wyniosły $234 \mathrm{mln}$ PLN, a do tego w całości wykorzystano środki zaplanowane na znajdowanie oraz promowanie nowych rynków zbytu na produkty rybne, tj. ponad $30 \mathrm{mln}$ PLN (Rynek ryb... 2009). Kontynuację działań i dalszy rozwój rynku umożliwiły środki z programu operacyjnego „Zrównoważony rozwój sektora rybołówstwa i nadbrzeżnych obszarów rybackich 2007-2013" (Kaliszewska 2016). Dzięki temu nasz kraj otrzymał szansę na zniwelowanie zaległości rozwojowych i sprostanie konkurencji poprzez możliwość partycypacji w programach pomocowych oraz środkach publicznych ${ }^{2}$ (funduszach pomocowych) jako instrumentach zewnętrznego zasilenia kapitałowego, z myślą o zwiększeniu innowacyjności i poprawie pozycji konkurencyjnej (w ramach sektora oraz na jednolitym rynku europejskim).

Ogólna produkcja ryb w Polsce wynosi około 500 tys. t, przy czym są to głównie ryby pochodzące z łowisk morskich, których ilość wykazuje w ostatnich latach tendencję malejącą, natomiast rośnie produkcja ryb z akwakultury (ryb słodkowodnych). Głównym rynkiem zbytu dla produktów rybnych pozostają kraje Unii Europejskiej ( $90 \%$ wartości), z dominującym udziałem Niemiec (53\%). Wolumen importu ryb, owoców morza oraz ich przetworów w 2016 r. wyniósł 564,1 tys. t, przy czym był o 5,8\% większy niż rok wcześniej, natomiast wydatki na ich zakup zwiększyły się o 19,4\% - do 1983,1 mln EUR. Znacznie pogłębiło się ujemne saldo wymiany handlowej branży rybnej - wyniosło 167,6 mln EUR, wobec 61,4 mln EUR w 2015 r.

W końcu września 2017 r. przetwórstwem ryb w Polsce zajmowały się 263 zakłady posiadające uprawnienia do handlu produktami na obszarze UE. Prawie połowa z nich (137) ulokowana była tylko w dwóch województwach - pomorskim i zachodniopomorskim.

Z uwagi na dostępność danych statystycznych przedmiotem rozważań w niniejszej pracy są przedsiębiorstwa sektora przetwórstwa rybnego, które w 2015 r. posiadały swoją siedzibę w województwie pomorskim. W badanym okresie na tym terenie funkcjonowały 72 podmioty gospodarcze, z czego do badań wybrano te, które wykorzystywały pomoce unijne, a więc korzystały z programów pomocowych, takich jak: SAPARD, sektorowy program operacyjny „Rybołówstwo i przetwórstwo ryb”, program operacyjny „Ryby” 2007-2013 (Zrównoważony rozwój sektora rybołówstwa i nadbrzeżnych obszarów rybackich).

\footnotetext{
2Zasady ogólne zarządzania środkami pochodzącymi z funduszy strukturalnych zostały określone w obowiązującej od 1 stycznia 2006 r. Ustawie o finansach publicznych z dnia 30 czerwca 2005 r. Zgodnie z ustawą środki pochodzące z budżetu UE, do których zalicza się m.in. środki pochodzące z funduszy strukturalnych, są środkami publicznymi (art. 5 ust. 1 pkt. 2 w związku z art. 5 ust. 3 pkt 2).
} 
Celem opracowania jest wykorzystanie analizy taksonomicznej do oceny sytuacji finansowej wybranych spółek. Badanie rozpoczęto od wyliczenia podstawowych wskaźników finansowych. Podstawową zaletą tych wskaźników jest to, że standaryzują pewne wielkości występujące w sprawozdaniach finansowych. Dzięki temu możliwe jest porównywanie relacji zachodzących $w$ firmach o różnej wielkości. Możliwość porównania wyników analizy danego przedsiębiorstwa $z$ innymi przedsiębiorstwami $z$ tego samego sektora może pomóc zarządzającym w przygotowaniu strategii, a inwestorom w podejmowaniu właściwych decyzji (Bąk i Szczecińska 2013). W dalszej części opracowania przeprowadzono porządkowanie i grupowanie spółek z wykorzystaniem metody unitaryzacji zerowanej.

\section{CHARAKTERYSTYKA WYBRANYCH SPÓŁEK}

Badanie obejmowało 39 spółek sektora przetwórstwa rybnego posiadających siedzibę na terenie województwa pomorskiego w 2015 r. Prowadziły one działalność w różnych formach organizacyjno-prawnych - dominowały spółki z ograniczoną odpowiedzialnością (54\%), co czwarta z nich była spółką jawną, sześć spółek (15\%) było spółkami akcyjnymi, jedna spółka była spółką cywilną i jedna - spółką komandytową.

Sytuacja finansowa przedsiębiorstwa jest odzwierciedleniem poziomu efektywności gospodarowania we wszystkich obszarach jego działalności. Poziom ten warunkuje rozwój przedsiębiorstwa i możliwość ciągłej reprodukcji sił wytwórczych, podejmowanie zamierzeń inwestycyjnych, a także wielkość i możliwość tworzenia zachęt materialnych dla pracowników. Ocenę efektywności gospodarowania można uzyskać poprzez informacje pochodzące z przeprowadzonej analizy finansowej przedsiębiorstwa. Największe znaczenie przypisuje się analizie wskaźnikowej ze względu na niską pracochłonność i kosztochłonność jej wykonania, w porównaniu z uzyskanymi informacjami. Ponadto porównanie wskaźników finansowych różnych podmiotów gospodarczych jednego sektora daje możliwość określenia ich pozycji konkurencyjnej. Najczęściej analizie poddawane są:

- wskaźniki płynności,

- wskaźniki wspomagania finansowego,

- wskaźniki obrotowości,

- wskaźnik rentowności.

Dobór konkretnych wskaźników do badania uzależniony jest od jego celu oraz dostępności danych. W niniejszym opracowaniu, na podstawie danych z bilansów i rachunków wyników, obliczono: dwa wskaźniki płynności, cztery wskaźniki zadłużenia, pięć wskaźników obrotowości oraz trzy wskaźniki rentowności.

W tabeli 1 zamieszczono uporządkowanie spółek na podstawie wskaźnika ROE (rentowności kapitałów własnych) informującego, jaka wartość zysku netto przypadała na złotówkę zainwestowanego kapitału własnego. Kluczowa rola tego wskaźnika w kształtowaniu strategii finansowej przedsiębiorstwa podkreślana jest wielokrotnie w literaturze przedmiotu. Tak przedstawiony poziom zyskowności przedsiębiorstwa umożliwia ocenę opłacalności zainwestowanych w firmie kapitałów, w odniesieniu do innych wariantowych form inwestowania (Bień 2000). Stopa zyskowności kapitałów własnych przesądza także w dużym stopniu o wartości udziałów (akcji), jakimi dysponują właściciele firmy, a także o aktualnej (rynkowej) jej wartości. W ten sposób można stwierdzić, które spółki charakteryzowały się najwyższą, a które najniższą rentownością. 
Tabela 1. Ranking badanych spółek według rentowności kapitału własnego w 2015 roku

\begin{tabular}{|c|c|c|c|c|c|}
\hline Lp. & Spółka & $\begin{array}{c}\text { Rentow- } \\
\text { ność } \\
\text { kapitału } \\
\text { własnego } \\
\text { ROE [\%] }\end{array}$ & $\begin{array}{c}\text { Rentow- } \\
\text { ność } \\
\text { majątku } \\
\text { ROA [\%] }\end{array}$ & $\begin{array}{l}\text { Rentow- } \\
\text { ność } \\
\text { sprzedaży } \\
\text { ROS [\%] }\end{array}$ & $\begin{array}{c}\text { Płynność } \\
\text { bieżąca }\end{array}$ \\
\hline 1 & Koryb PH, W. Kołodziejski Sp. j. & 74,07 & 17,73 & 4,22 & 1,18 \\
\hline 2 & Paula Fish Sp. j. & 45,05 & 7,96 & 7,01 & 1,02 \\
\hline 3 & Sulmin Sp. j. & 44,72 & 24,51 & 8,22 & 2,34 \\
\hline 4 & Mors W.B. Michalak Sp. j. & 37,39 & 14,59 & 11,28 & 1,42 \\
\hline 5 & Proryb Dyzman Sp. z o.o & 32,53 & 2,78 & 2,55 & 1,09 \\
\hline 6 & Rafa Sp. j. & 30,83 & 9,60 & 2,93 & 1,13 \\
\hline 7 & Gadus Sp. z o.o. & 30,19 & 6,28 & 3,02 & 0,83 \\
\hline 8 & King Oscar Sp. z o.o. & 30,10 & 13,89 & 8,86 & 1,43 \\
\hline 9 & Ryby Mielewczyk Sp. j. & 25,26 & 13,39 & 5,34 & 2,48 \\
\hline 10 & Ajtel Sp. j. & 22,12 & 18,87 & 10,32 & 5,01 \\
\hline 11 & Jantar Ltd Sp. z o.o. & 21,97 & 8,43 & 9,79 & 1,81 \\
\hline 12 & Evrafish Sp. z o.o. & 21,37 & 5,83 & 4,80 & 1,85 \\
\hline 13 & Wodnik Stolarczyk \& Osipowski SC & 19,74 & 7,16 & 5,88 & 2,41 \\
\hline 14 & Arpol Sp. z o.o. & 19,57 & 4,64 & 2,36 & 1,23 \\
\hline 15 & Laguna Ustarbowski, Rekowski Sp. j. & 18,30 & 3,36 & 1,86 & 1,15 \\
\hline 16 & Morex Sp. z o.o. & 16,51 & 2,14 & 0,96 & 1,15 \\
\hline 17 & Koral SA & 14,39 & 4,45 & 2,29 & 0,77 \\
\hline 18 & Baltic United Sp. k. & 12,85 & 3,04 & 1,87 & 1,04 \\
\hline 19 & Koga-Maris Sp. z o.o. & 12,08 & 7,87 & 18,27 & 7,39 \\
\hline 20 & Graal SA & 9,32 & 6,31 & 4,55 & 1,50 \\
\hline 21 & Seko SA & 8,78 & 4,63 & 3,55 & 1,80 \\
\hline 22 & Mirko ZPR Sp.z o.o. & 8,44 & 2,48 & 13,96 & 0,97 \\
\hline 23 & Kotwica Konkel Sp. j. & 8,29 & 6,35 & 3,11 & 3,47 \\
\hline 24 & Łosoś Sp. z o.o. & 7,04 & 3,02 & 2,21 & 1,51 \\
\hline 25 & Laurin Sp. z o.o. & 5,99 & 3,16 & 1,35 & 1,48 \\
\hline 26 & Rieber Foods Polska Sp. z o.o. & 4,59 & 2,67 & 1,42 & 1,75 \\
\hline 27 & Almar Sp. z o.o. & 3,93 & 1,22 & 0,92 & 1,90 \\
\hline 28 & Fario Sp. j. & 3,45 & 0,62 & 0,23 & 1,11 \\
\hline 29 & Kordex Sp.z o.o. & 3,42 & 1,51 & 0,75 & 1,07 \\
\hline 30 & Dos Sp. z o.o. & 2,76 & 0,61 & 0,40 & 0,76 \\
\hline 31 & Polinord Sp. z o.o. & 2,07 & 0,54 & 0,35 & 0,82 \\
\hline 32 & Nord Capital Sp. z o.o. & 1,10 & 0,24 & 0,14 & 1,18 \\
\hline 33 & Wilbo SA & 0,73 & 0,11 & 0,08 & 2,33 \\
\hline 34 & Superfish SA & $-1,25$ & $-0,01$ & $-1,55$ & 4,59 \\
\hline 35 & Morpol SA & $-4,31$ & $-0,92$ & $-0,51$ & 1,29 \\
\hline 36 & Morfish Sp. z o.o. & $-4,59$ & $-1,21$ & $-121,23$ & 0,56 \\
\hline 37 & Szkuner Sp. z o.o. & $-6,61$ & $-3,36$ & $-12,17$ & 2,11 \\
\hline 38 & Artryb Sp. z o.o. & $-8,32$ & $-5,50$ & $-1,94$ & 0,51 \\
\hline 39 & Inletta Sp. z o.o. & $-153,75$ & $-7,16$ & $-313,37$ & 2,33 \\
\hline
\end{tabular}

Źródło: obliczono na podstawie bilansów oraz rachunków zysków i strat poszczególnych spółek za rok 2015. 
Na szczycie rankingu znalazła się spółka Koryb z ok. 74\% ROE. Tak wysoki poziom wskaźnika rentowności kapitałów własnych świadczy o przemyślanej strategii finansowej realizowanej w firmie. Trzecie miejsce zajęła spółka Sulmin, która charakteryzuje się nieznacznie niższym ROE, niż druga w rankingu Paula Fish, ale na uwagę zasługują wysokie poziomy pozostałych wskaźników rentowności, a w szczególności wskaźnika ROA najwyższego wśród badanych spółek. W najgorszej sytuacji finansowej znalazło się sześć $(15,4 \%)$ poddanych badaniu spółek, które w 2015 r. były nierentowne (Inletta, Artryb, Szkuner, Morfish, Morpol, Superfish).

W tabeli 1 zamieszczono również wskaźnik bieżącej płynności (relacja majątku obrotowego do zobowiązań krótkoterminowych), ponieważ ryzyko utraty zdolności do terminowego regulowania przez firmę zobowiązań bieżących może pojawiać się także w przedsiębiorstwach osiągających wysokie zyski. Naruszenie bowiem równowagi pomiędzy terminami wpływu gotówki a koniecznymi wydatkami na pokrycie zobowiązań w dłuższym okresie może doprowadzić firmę do upadłości. Utrata płynności prowadzi do zmniejszenia zaufania banków, kontrahentów i w konsekwencji do kurczenia się obszaru działania na rynku (Sierpińska i Wędzki 1998). Za wartość optymalną tego wskaźnika uznaje się wartość wahająca się w przedziale od 1,2 do 2,0 (Gabrusewicz 2014). Wśród badanych spółek kryterium to spełniło 12. Natomiast 17 spółek, tj. ok. 45\% miało zdecydowanie za niski poziom płynności (poniżej 1,2), co wskazuje na kłopoty z terminowym regulowaniem zobowiązań krótkoterminowych. Dwie spółki (Koga-Maris, Ajtel) charakteryzowały się z kolei zamrożeniem nadmiernie wysokich kapitałów własnych w finansowaniu bieżącej działalności i niemożnością zwiększenia ich zyskowności poprzez efektywne wykorzystanie obcych kapitałów, co może mieć niekorzystny wpływ na rentowność przedsiębiorstwa (płynność powyżej 5).

Wskaźniki wspomagania finansowego umożliwiają określenie poziomu zadłużenia podmiotu gospodarczego, a więc tym samym oceniają jego wypłacalność w długim okresie. W praktyce poziom zadłużenia długo- i średnioterminowego ocenia się w odniesieniu do kapitału własnego ewentualnie stałego (Waśniewski i Skoczylas 1997).

W tabeli 2 przedstawiono charakterystykę spółek pod względem ogólnego zadłużenia. Rosnący poziom tego wskaźnika oznacza wyższy stopień udziału kapitału obcego w działalności przedsiębiorstwa. Wzrost zobowiązań w stosunku do majątku może być uzasadniony głównie wówczas, gdy przeciętne oprocentowanie kredytów i pożyczek jest niższe od stopy rentowności majątku osiąganej przez przedsiębiorstwo (Bednarski 2002).

$\mathrm{Na}$ pierwszym miejscu tabeli znalazła się spółka Inletta, która charakteryzowała się najwyższym stopniem zadłużenia, o czym świadczą trzy pierwsze wskaźniki. Zobowiązania długo-terminowe przedsiębiorstwa powinny znajdować formalnoprawne zabezpieczenie w majątku trwałym. Dlatego w ocenie sytuacji finansowej wykorzystuje się wskaźnik pokrycia majątku trwałego zobowiązaniami długoterminowymi. Wyjaśnia on, ile razy wartość środków trwałych pozostających w dyspozycji przedsiębiorstwa przekracza zaciągnięte kredyty i pożyczki długoterminowe (Bednarski 2002). W najbardziej zadłużonej spółce wskaźnik ten wynosił 1,44 - w odniesieniu do innych spółek, które zaciągnęły zobowiązania długoterminowe, nie jest to zły wynik.

Najniższy wskaźnik ogólnego zadłużenia dotyczył Superfish SA, która w badanym roku była spółką nierentowną. 
Tabela 2. Ranking badanych spółek według wskaźnika ogólnego zadłużenia w 2015 roku

\begin{tabular}{|c|c|c|c|c|c|}
\hline Lp. & Spółka & $\begin{array}{c}\text { Wskaźnik } \\
\text { ogólnego } \\
\text { zadłużenia }\end{array}$ & $\begin{array}{c}\text { Wskaźnik } \\
\text { udziału } \\
\text { kapitału } \\
\text { własnego } \\
\text { w finanso- } \\
\text { waniu } \\
\text { majątku }\end{array}$ & $\begin{array}{c}\text { Wskaźnik } \\
\text { relacji } \\
\text { zobowiązań } \\
\text { do kapitału } \\
\text { własnego }\end{array}$ & $\begin{array}{c}\text { Wskaźnik } \\
\text { pokrycia } \\
\text { majątku } \\
\text { trwałego } \\
\text { zobowiąza- } \\
\text { niami } \\
\text { długotermi- } \\
\text { nowymi }\end{array}$ \\
\hline 1 & Inletta Sp. z o.o. & 0,953 & 0,047 & 13,559 & 1,441 \\
\hline 2 & Proryb Dyzman Sp. z o.o & 0,915 & 0,085 & 10,705 & 0,000 \\
\hline 3 & Morex Sp. z o.o. & 0,871 & 0,129 & 5,764 & 2,953 \\
\hline 4 & Wilbo SA & 0,852 & 0,148 & 3,310 & 1,687 \\
\hline 5 & Paula Fish Sp. j. & 0,823 & 0,177 & 3,061 & 3,805 \\
\hline 6 & Fario Sp. j. & 0,820 & 0,180 & 4,024 & 4,328 \\
\hline 7 & Laguna Ustarbowski, Rekowski Sp. j. & 0,816 & 0,184 & 3,608 & 3,027 \\
\hline 8 & Gadus Sp. z o.o. & 0,792 & 0,208 & 3,547 & 3,126 \\
\hline 9 & Morpol SA & 0,786 & 0,214 & 3,674 & 1,253 \\
\hline 10 & Dos Sp. z o.o. & 0,779 & 0,221 & 3,006 & 0,000 \\
\hline 11 & Nord Capital Sp. z o.o. & 0,778 & 0,222 & 2,657 & 3,603 \\
\hline 12 & Arpol Sp. z o.o. & 0,763 & 0,237 & 2,971 & 1,719 \\
\hline 13 & Baltic United Sp. k. & 0,763 & 0,237 & 2,306 & 5,364 \\
\hline 14 & Koryb PH, W. Kołodziejski Sp. j. & 0,761 & 0,239 & 26,916 & 20,797 \\
\hline 15 & Polinord Sp. z o.o. & 0,741 & 0,259 & 2,856 & 3,034 \\
\hline 16 & Morfish Sp. z o.o. & 0,736 & 0,264 & 6,632 & 0,000 \\
\hline 17 & Evrafish Sp. z o.o. & 0,727 & 0,273 & 2,252 & 1,511 \\
\hline 18 & Mirko ZPR Sp.z o.o. & 0,706 & 0,294 & 1,793 & 2,840 \\
\hline 19 & Koral SA & 0,691 & 0,309 & 2,205 & 11,467 \\
\hline 20 & Almar Sp. z o.o. & 0,690 & 0,310 & 2,223 & 0,275 \\
\hline 21 & Rafa Sp. j. & 0,689 & 0,311 & 2,034 & 10,516 \\
\hline 22 & Wodnik Stolarczyk \& Osipowski SC & 0,637 & 0,363 & 0,743 & 4,533 \\
\hline 23 & Jantar Ltd Sp. z o.o. & 0,616 & 0,384 & 1,605 & 1,498 \\
\hline 24 & Mors W.B. Michalak Sp. j. & 0,610 & 0,390 & 0,904 & 12,073 \\
\hline 25 & Łosoś Sp. z o.o. & 0,571 & 0,429 & 1,062 & 4,542 \\
\hline 26 & Kordex Sp.z o.o. & 0,559 & 0,441 & 1,269 & 10,533 \\
\hline 27 & King Oscar Sp. z o.o. & 0,538 & 0,462 & 1,101 & 15,179 \\
\hline 28 & Szkuner Sp. z o.o. & 0,493 & 0,507 & 0,594 & 3,543 \\
\hline 29 & Seko SA & 0,473 & 0,527 & 0,702 & 4,869 \\
\hline 30 & Laurin Sp. z o.o. & 0,472 & 0,528 & 0,895 & 14,948 \\
\hline 31 & Ryby Mielewczyk Sp. j. & 0,470 & 0,530 & 0,595 & 5,079 \\
\hline 32 & Sulmin Sp. j. & 0,452 & 0,548 & 11,890 & 0,049 \\
\hline 33 & Rieber Foods Polska Sp. z o.o. & 0,418 & 0,582 & 0,582 & 0,000 \\
\hline 34 & Koga-Maris Sp. z o.o. & 0,349 & 0,651 & 0,051 & 0,000 \\
\hline 35 & Artryb Sp. z o.o. & 0,338 & 0,662 & 0,511 & 0,000 \\
\hline 36 & Graal SA & 0,324 & 0,676 & 0,478 & 11,171 \\
\hline 37 & Kotwica Konkel Sp. j. & 0,234 & 0,766 & 0,181 & 0,000 \\
\hline 38 & Ajtel Sp. j. & 0,147 & 0,853 & 0,172 & 0,000 \\
\hline 39 & Superfish SA & 0,002 & 0,008 & 0,189 & 11,042 \\
\hline
\end{tabular}

Źródło: obliczono na podstawie bilansów oraz rachunków zysków i strat poszczególnych spółek za rok 2015. 


\section{ZASTOSOWANIE ANALIZY TAKSONOMICZNEJ DO SYNTETYCZNEJ OCENY BADANYCH SPÓŁEK}

\section{Dobór cech diagnostycznych}

Klasyfikacja obiektów społeczno-gospodarczych (spółek) za pomocą metod taksonomicznych wymaga w sposób wszechstronny określenia zestawu cech charakteryzujących te obiekty, czyli tzw. cech diagnostycznych. Od prawidłowego doboru tych cech w znacznym stopniu zależą wyniki badania, bez względu na stosowane w późniejszym etapie badania techniki i metody (Panek 2009; Piramuthu 2004). Głównymi kryteriami wyboru cech były przesłanki merytoryczne i formalne ze względu na realizację celu badań. Istotnym kryterium była również dostępność danych statystycznych. Doprowadziło to do uzyskania następującego finalnego zbioru cech diagnostycznych:

$X_{1}$ - wskaźnik bieżącej płynności (relacja majątku obrotowego do zobowiązań bieżących),

$X_{2}$ - wskaźnik szybkiej płynności (relacja majątku obrotowego pomniejszonego o wartość zapasów do zobowiązań bieżących),

$X_{3}$ - wskaźnik ogólnego zadłużenia (relacja ogółu zobowiązań do całości majątku),

$X_{4}$ - wskaźnik udziału kapitału własnego w finansowaniu majątku,

$X_{5}$ - wskaźnik relacji zobowiązań do kapitału własnego,

$X_{6}$ - wskaźnik pokrycia majątku trwałego zobowiązaniami długoterminowymi,

$X_{7}$ - wskaźnik obrotowości majątku (relacja przychodów ze sprzedaży do przeciętnego stanu zaangażowanych składników majątkowych),

$X_{8}$ - wskaźnik obrotowości majątku trwałego (relacja przychodów ze sprzedaży do przeciętnego stanu majątku trwałego),

$X_{9}$-wskaźnik obrotowości majątku obrotowego (relacja przychodów ze sprzedaży do przeciętnego stanu majątku obrotowego),

$X_{10}$ - wskaźnik rotacji zapasów w dniach (relacja przeciętnego stanu zapasów do kosztów działalności operacyjnej),

$X_{11}$ - wskaźnik czasu rozliczenia należności (relacja należności z tytułu dostaw, robót i usług do przychodów ze sprzedaży),

$X_{12}$ - wskaźnik rentowności sprzedaży netto ROS (relacja wyniku finansowego netto do przychodów ze sprzedaży),

$X_{13}$ - wskaźnik rentowności majątku ROA (relacja wyniku finansowego netto do majątku ogółem),

$X_{14}$ - wskaźnik rentowności kapitału własnego ROE (relacja wyniku finansowego netto do kapitału własnego).

Wyżej wymieniony zbiór potencjalnych cech diagnostycznych, ustalony na podstawie kryteriów merytoryczno-formalnych podlega następnie weryfikacji ze względu na wartość informacyjną cech. Weryfikacja ta odbywa się za pomocą procedur statystycznych uwzględniających dwa podstawowe kryteria (Panek 2009):

- zdolność dyskryminacyjną cech, czyli ich zmienność w odniesieniu do badanych obiektów;

- pojemność (potencjał informacyjny) cech, czyli stopień ich skorelowania z innymi cechami.

Biorąc pod uwagę pierwsze z wyżej wymienionych kryteriów, żadnej z potencjalnych cech diagnostycznych nie wyeliminowano z badania, gdyż obliczone dla nich współczynniki zmienności były bardzo wysokie (od 35\% do 683\%). Ponadto należy dodać, że wszystkie 
cechy diagnostyczne charakteryzowały się silną lub bardzo silną asymetrią. W kolejnym kroku, w celu wyeliminowania cech o podobnym potencjale informacyjnym, zastosowano metodę Hellwiga ${ }^{3}$. Pozwoliło to na ustalenie ostatecznej listy cech diagnostycznych, będącej podstawą dalszej analizy porównawczej. W zbiorze cech diagnostycznych znalazły się wskaźniki, których większe wartości świadczą o lepszej sytuacji finansowej badanych spółek (stymulanty) oraz te wskaźniki, w przypadku których pożądany jest ich niższy poziom (destymulanty). Do zbioru destymulant zaliczono: $X_{3}, X_{5}, X_{10}$ pozostałe cechy to stymulanty $\left(X_{6}, X_{7}, X_{8}, X_{12}\right)$.

\section{Ranking badanych spółek sektora przetwórstwa rybnego}

$\mathrm{Na}$ podstawie otrzymanych zbiorów cech przystąpiono do wyznaczenia syntetycznego wskaźnika dla poszczególnych spółek. Ponieważ cechy diagnostyczne mają różne miana i różne zakresy zmienności, nie można ich bezpośrednio porównywać i dodawać. Należy cechy te doprowadzić do porównywalności, dokonując odpowiednich transformacji pozbawiających je mian, i ujednolicić zakres zmienności. W pracy zastosowano metodę unitaryzacji zerowanej (Kukuła 2000). W metodzie tej stosuje się następujące przekształcenia:

- dla stymulant $z_{i j}=\frac{x_{i j}-\min _{i} x_{i j}}{\max _{i} x_{i j}-\min _{i} x_{i j}}, \max _{i} x_{i j} \neq \min _{i} x_{i j}$

- dla destymulant $z_{i j}=\frac{\max _{i} x_{i j}-x_{i j}}{\max _{i} x_{i j}-\min _{i} x_{i j}}, \max _{i} x_{i j} \neq \min _{i} x_{i j}$

Taki sposób normalizacji powoduje, że wszystkie wartości cech znormalizowanych należą do przedziału $[0,1]$. Syntetyczną miarę rozwoju $\left(z_{i}\right)$ buduje się jako średnią arytmetyczną unormowanych wartości cech diagnostycznych:

$$
z_{i}=\frac{1}{k} \sum_{i=1}^{k} z_{i j},
$$

gdzie: $k$ - liczba cech diagnostycznych.

Zmienną syntetyczną $z_{i}$ można uznać za miernik syntetyczny, gdyż przyjmuje wartości z przedziału [0;1]. Na podstawie wartości miernika syntetycznego $z_{i}$ można wyodrębnić cztery grupy typologiczne, obejmujące obiekty o wartościach $z$ następujących przedziałów: grupa 1: $z_{i} \geq \bar{z}+s_{z}$; grupa 2: $\bar{z}+s_{z}>z_{i} \geq \bar{z}$; grupa 3: $\bar{z}>z_{i} \geq \bar{z}-s_{z}$; grupa 4: $z_{i}<\bar{z}-s_{z}$. Wyniki badania przedstawiono w tab. 3 .

W pierwszej grupie znalazło się pięć spółek (ok. 13\%) charakteryzujących się najlepszą sytuacją finansową. Świadczyły o tym wysokie wskaźniki rentowności i efektywności wykorzystania majątku (por. np. ryc. 2) oraz niskie wskaźniki zadłużenia (por. np. ryc. 1). Najliczniejsza okazała się grupa druga, do której zaliczono 15 spółek $(38,5 \%)$ osiągających dobre wyniki (w porównaniu ze średnimi ogólnymi), szczególnie w zakresie gospodarowania majątkiem oraz rentowności. Tylko jeden obiekt mniej (14 spółek) znalazł się w trzeciej grupie o kondycji finansowej poniżej przeciętnej. Skupienie to charakteryzuje się gorszymi

\footnotetext{
${ }^{3}$ Opis metody można znaleźć np. w pracach: Nowak (1990), Malina (2004), Młodak (2006), Panek (2009).
} 
wartościami przeciętnymi, niż grupy I i II, w przypadku wszystkich przyjętych do badania wskaźników. Ostatnią grupę stanowi pięć spółek o najgorszej sytuacji finansowej, o czym świadczą niekorzystne wskaźniki finansowe.

Tabela 3. Ranking badanych spółek według wskaźnika syntetycznego w 2015 roku

\begin{tabular}{|c|c|c|c|}
\hline Lp. & Spółka & Miernik & Grupa typologiczna \\
\hline 1 & Laurin Sp. z o.o. & 0,7347 & \multirow{5}{*}{1} \\
\hline 2 & Rafa Sp. j. & 0,7031 & \\
\hline 3 & Superfish SA & 0,6857 & \\
\hline 4 & Almar Sp. z o.o. & 0,6842 & \\
\hline 5 & Ajtel Sp. j. & 0,6821 & \\
\hline 6 & Ryby Mielewczyk Sp. j. & 0,6726 & \multirow{15}{*}{ II } \\
\hline 7 & Artryb Sp. z o.o. & 0,6690 & \\
\hline 8 & Kordex Sp.z o.o. & 0,6634 & \\
\hline 9 & Graal SA & 0,6602 & \\
\hline 10 & Kotwica Konkel Sp. j. & 0,6520 & \\
\hline 11 & Koral SA & 0,6509 & \\
\hline 12 & King Oscar Sp. z o.o. & 0,6419 & \\
\hline 13 & Fario Sp. j. & 0,6394 & \\
\hline 14 & Mors W.B. Michalak Sp. j. & 0,6277 & \\
\hline 15 & Sulmin Sp. j. & 0,6227 & \\
\hline 16 & Rieber Foods Polska Sp. z o.o. & 0,6226 & \\
\hline 17. & Koryb PH, W. Kołodziejski Sp. j. & 0,6215 & \\
\hline 18 & Seko SA & 0,6126 & \\
\hline 19 & Gadus Sp. z o.o. & 0,5960 & \\
\hline 20 & Wodnik Stolarczyk \& Osipowski SC & 0,5837 & \\
\hline 21 & Łosoś Sp. z o.o. & 0,5743 & \multirow{14}{*}{ III } \\
\hline 22 & Baltic United Sp. k. & 0,5698 & \\
\hline 23 & Morex Sp. z o.o. & 0,5687 & \\
\hline 24 & Nord Capital Sp.z o.o. & 0,5669 & \\
\hline 25 & Polinord Sp. z o.o. & 0,5617 & \\
\hline 26 & Paula Fish Sp. j. & 0,5531 & \\
\hline 27 & Koga-Maris Sp. z o.o. & 0,5505 & \\
\hline 28 & Morpol SA & 0,5471 & \\
\hline 29 & Dos Sp. z o.o. & 0,5435 & \\
\hline 30 & Szkuner Sp. z o.o. & 0,5426 & \\
\hline 31 & Laguna Ustarbowski, Rekowski Sp. j. & 0,5386 & \\
\hline 32 & Evrafish Sp. z o.o. & 0,5331 & \\
\hline 33 & Wilbo SA & 0,5087 & \\
\hline 34 & Jantar Ltd Sp. Z o.o. & 0,4873 & \\
\hline 35 & Proryb Dyzman Sp.z o.o & 0,4782 & \multirow{5}{*}{ IV } \\
\hline 36 & Arpol Sp. z o.o. & 0,4692 & \\
\hline 37 & Mirko ZPR Sp.z o.o. & 0,4598 & \\
\hline 38 & Morfish Sp. z o.o. & 0,3238 & \\
\hline 39 & Inletta Sp. z o.o. & 0,2611 & \\
\hline
\end{tabular}


Na ryc. 1 i 2 pokazano, jak kształtowały się średnie wskaźniki ogólnego zadłużenia oraz obrotowości majątku trwałego w wyodrębnionych grupach w 2015 roku.

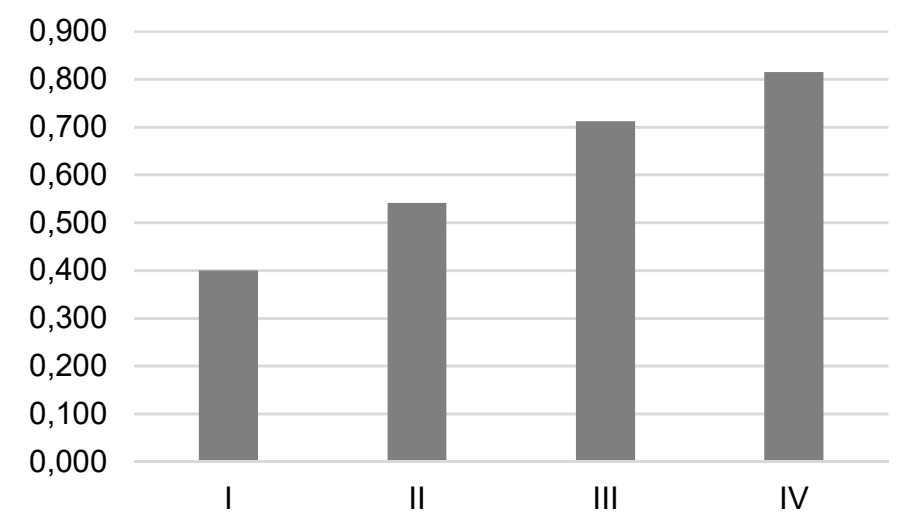

Ryc. 1. Średni wskaźnik ogólnego zadłużenia w grupach typologicznych w 2015 roku

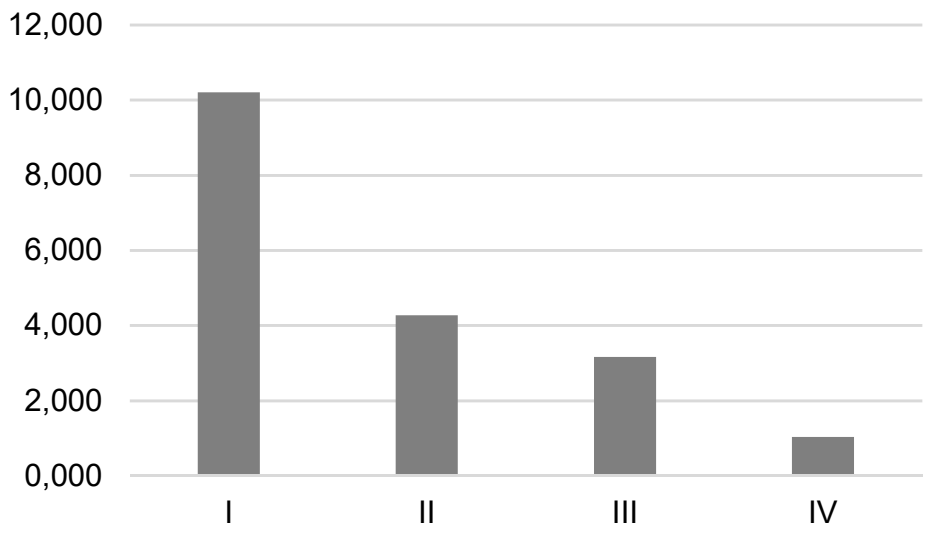

Ryc. 2. Średni wskaźnik obrotowości majątku trwałego w grupach typologicznych w 2015 roku

Przedstawione na ryc. 1 i 2 wskaźniki jednoznacznie potwierdzają sytuację finansową spółek należących do wyodrębnionych grup typologicznych. Średni wskaźnik ogólnego zadłużenia w pierwszej grupie jest o połowę niższy niż w grupie czwartej. Natomiast różnica pomiędzy średnimi wskaźnikami obrotowości majątku w grupach pierwszej i czwartej przekracza dziewięć, co wskazuje na zdecydowanie wyższą efektywność wykorzystania majątku.

\section{PODSUMOWANIE}

Zastosowanie powszechnie stosowanej analizy finansowej, wykorzystującej porównanie różnych wskaźników do oceny kondycji finansowej przedsiębiorstw, może dawać niejednoznaczne wyniki. Zarządzający oraz inwestorzy mogą mieć problem w określeniu, która firma jest lepsza czy ta o wyższych wskaźnikach rentowności czy ta o lepszej płynności? Dlatego rozszerzenie badań o metody analizy taksonomicznej jest wskazane, szczególnie w przypadku wykorzystywania wielu zróżnicowanych cech diagnostycznych (Bąk i Szczecińska 2013). 
Okazuje się, że jednoznaczna ocena sytuacji finansowej spółek nie jest łatwym zadaniem i w dużym stopniu może być uzależniona od zaproponowanego na wstępie badania zbioru wskaźników finansowych i prawdopodobnie od zastosowanej metody. Ponadto zastosowanie procedury formalnostatystycznej wyboru cech znacznie zmniejsza pierwotny zbiór cech diagnostycznych, a to z kolei ogranicza możliwości interpretacyjne otrzymanych wyników badanego zjawiska.

Analiza porównawcza sytuacji finansowej wybranych spółek sektora przetwórstwa rybnego w województwie pomorskim w 2015 roku, z wykorzystaniem metody unitaryzacji zerowanej, pozwoliła na wyodrębnienie czterech grup spółek zbliżonych pod względem badanego zjawiska. Szczególnie istotne może to być dla zarządzających, dla których miejsce spółki w rankingu, a tym samym przynależność jej do określonej grupy typologicznej, pozwala wskazać pozycję konkurencyjną tej spółki w badanym sektorze. Pomóc to może w podejmowaniu decyzji dotyczących inwestycji oraz w budowaniu strategii. Tego rodzaju analizy powinny być kontynuowane w kolejnych latach, co pozwoli na ocenę efektywności działalności i kierunku zmian badanych spółek.

\section{PIŚMIENNICTWO}

Bąk I., Szczecińska B. 2013. Wykorzystanie analizy taksonomicznej do wyznaczenia rankingu spółek sektora spożywczego notowanych na Giełdzie Papierów Wartościowych w Warszawie. Ekonometria 4(42), 72-84.

Bednarski L. 2002. Analiza finansowa w przedsiębiorstwie. Warszawa, PWE, 83, 80.

Bień W. 2000. Zarządzanie finansami przedsiębiorstwa. Warszawa, Difin, 16.

Czapliński P. 2018. Przemiany w polskim przemyśle przetwórstwa rybnego. Pr. Komis. Geogr. Przem. Pol. Tow. Geogr. 32(2), 115, 63.

Gabrusewicz W. 2014. Analiza finansowa przedsiębiorstwa. Teoria i zastosowanie. Warszawa, PWE.

Kaliszewska M. 2016. Charakterystyka przetwórstwa rybnego w Polsce w latach 2006-2014 na podstawie kwestionariuszy statystycznych RW-20, w: 95-lecie Morskiego Instytutu Rybackiego. Aktualne tematy badań naukowych. T. III. Produkty i przetwory rybne. Red. I. Psuta. Gdynia, MIR-PIB, 16, 6-7.

Kukuła K. 2000. Metoda unitaryzacji zerowanej. Warszawa, PWN, 60-92.

Malina A. 2004. Wielowymiarowa analiza przestrzennego zróżnicowania struktury gospodarki Polski według województw. Kraków, Wydaw. AE.

Młodak A. 2006. Analiza taksonomiczna w statystyce regionalnej. Warszawa, Difin, 136-141.

Nowak E. 1990. Metody taksonomiczne w klasyfikacji obiektów społeczno-gospodarczych. Warszawa, PWE.

Nowak R.Z. 2005. Fundusze strukturalne UE, jako czynnik mobilizacji gospodarki polskiej, Regionalizm, polityka regionalna i Fundusze Strukturalne w Unii Europejskiej. Red. A. Adamczyka, J. Brokowskiego. Centrum Europejskie, Uniwersytet Warszawski, 69.

Panek T. 2009. Statystyczne metody wielowymiarowej analizy porównawczej. Warszawa, SGH, 16.

Piramuthu S. 2004. Evaluating feature selection methods for learning in data mining applications. Europ. J. Operat. Res. 156(2), 483-494.

Rynek ryb - stan i perspektywy. 2009. Red. K. Hryszko. Analizy Rynkowe nr 12, Warszawa, Wydaw. IERiGŻ-PIB, 9.

Sytuacja na światowym rynku ryb i jej wpływ na rozwój sektora rybnego w Polsce. 2014. Red. K. Hryszko. Warszawa, Wydaw. IERiGŻ-PIB, 91. 
Sierpińska M., Wędzki D. 1998. Zarządzanie płynnością finansową w przedsiębiorstwie. Warszawa, PWN, 7.

Ustawa o finansach publicznych z dnia 30 czerwca 2005 r. DzU nr 249, poz. 2104, ze zm.

Waśniewski T., Skoczylas W. 1997. Analiza finansowa w przedsiębiorstwie. Poznań, Wydaw. WSB, 55.

Streszczenie. Sektor przetwórstwa rybnego jest jednym z najszybciej rozwijających się sektorów rolno-spożywczych. Głównym czynnikiem mającym wpływ na jego rozwój w Polsce były fundusze Unii Europejskiej, dzięki którym kraj nasz otrzymał szansę na zniwelowanie zaległości rozwojowych, zwiększenie innowacyjności i poprawę pozycji konkurencyjnej (w ramach sektora oraz na jednolitym rynku europejskim). Celem artykułu jest wykorzystanie analizy taksonomicznej do oceny sytuacji finansowej spółek sektora przetwórstwa rybnego. W badaniu uwzględniono spółki, które korzystały $z$ funduszy unijnych i funkcjonowały w województwie pomorskim w 2015 roku. Porządkowanie i grupowanie spółek przeprowadzono, wykorzystując metodę unitaryzacji zerowanej. 